\title{
Genomic Characterization, Formulation and Efficacy in Planta of a Siphoviridae and Podoviridae Protection Cocktail against the Bacterial Plant Pathogens Pectobacterium spp.
}

\author{
Maja A. Zaczek-Moczydłowska ${ }^{1, *}$, Gillian K. Young ${ }^{2}$, James Trudgett $^{3}$, Colin C. Fleming $^{2}{ }^{(}$, \\ Katrina Campbell ${ }^{1}$ and Richard $\mathrm{O}^{\prime} \mathrm{Hanlon}^{2}$ \\ 1 Institute for Global Food Security, School of Biological Sciences, Queen's University, Belfast BT9 5DL, UK; \\ katrina.campbell@qub.ac.uk \\ 2 Sustainable Agri-Food Sciences Division, Agri-Food and Biosciences Institute, Belfast, BT9 5PX UK; \\ Gillian.Young@afbini.gov.uk (G.K.Y.); Colin.Fleming@afbini.gov.uk (C.C.F.); \\ Richard.OHanlon@afbini.gov.uk (R.O.H.) \\ 3 Veterinary Sciences Division, Agri-Food and Biosciences Institute, Stormont, Belfast BT4 3SD, UK; \\ James.Trudgett@afbini.gov.uk \\ * Correspondence: mzaczekmoczydlowska01@qub.ac.uk
}

Received: 13 December 2019; Accepted: 25 January 2020; Published: 28 January 2020

\begin{abstract}
In the face of global human population increases, there is a need for efficacious integrated pest management strategies to improve agricultural production and increase sustainable food production. To counteract significant food loses in crop production, novel, safe and efficacious measures should be tested against bacterial pathogens. Pectobacteriaceae species are one of the causative agents of the bacterial rot of onions ultimately leading to crop losses due to ineffective control measures against these pathogens. Therefore, the aim of this study was to isolate and characterize bacteriophages which could be formulated in a cocktail and implemented in planta under natural environmental conditions. Transmission electron microscopy (TEM) and genome analysis revealed Siphoviridae and Podoviridae family bacteriophages. To test the protective effect of a formulated phage cocktail against soft rot disease, three years of field trials were performed, using three different methods of treatment application. This is the first study to show the application of a phage cocktail containing Podoviridae and Siphoviridae bacteriophages capable of protecting onions against soft rot in field conditions.
\end{abstract}

Keywords: bacteriophages; phage cocktail; Pectobacteriacea; biocontrol

\section{Introduction}

Despite recent advances in food shelf-life extension technologies, improved varieties of crops and more efficient food distribution systems, food waste has been estimated at 1.3 billion tons per year, which is equal to one-third of all food produced for human consumption [1]. Food is wasted throughout the food supply chain, with significant loss and waste during agricultural production in economically important crops such as potato [1]. Plant diseases, caused by a wide range of pests (including pathogens), are among the largest causes of global crop losses, estimated to be $27-42 \%$ in production systems [2]. The production of onions (Allium cepa L.) is of high economic importance, representing $12 \%$, by mass, of global production of vegetables (93.16 million tons). The most intensive production of onions occurs in Asia with $62.2 \%$, Africa at $12.5 \%$ and Europe at $10.6 \%$, with the global gross production value evaluated at up to US $\$ 42.1$ million [3]. Appropriate control measures for onions against bacterial rot disease are difficult to achieve, given that at least 26 different fungi and 
bacteria are associated with this rot [4]. Onion rot may ultimately cause significant post-harvest losses, with disease beginning in the field and developing further during transit and storage [5]. Thus far, soft rot disease management mainly consists of preventative measures based on good plant handling hygiene, with no biological or chemical control agents available commercially [6].

The most destructive pathogens reported to cause disease in onions are Xanthomonas retroflexus (leaf blight), Pseudomonas viridiflava and Xanthomonas spp. (bacterial streak and bulb rot) [5]. A diverse range of bacteria causing soft rot of onions have been reported, including Pseudomonas spp. (e.g., Pseudomonas marginalis, Pseudomonas allicola, and Pseudomonas cepacia) [5,7], Pectobacterium spp. (Pectobacterium carotovorum subsp. carotovorum (P. c. subsp. carotovorum) and Pectobacterium carotovorum subsp. odoriferum) [8], and Dickeya spp. (e.g. Dickeya chrysanthemi, Dickeya fangzhongdai) [9,10].

Previous phage therapy trials in greenhouses and field conditions have been carried out against soft rot Pectobacteriaceae (SRP) of potato, including Dickeya sp. [11] and Pectobacterium spp. [12,13]. Bacteriophages have been evaluated as phage therapy in agriculture to combat threats related to pathogenic bacterial species such Erwinia amylovora, Xantomonas campestris or Dickeya spp. [14], with one report describing attempts to control onion blight disease of onions (causal agent Xanthomonas sp.) using a bacteriophage formulation [15]. Phage cocktails used against soft rot have been designed based on lytic activity and host range, using methods such as overlay, spotting assays, killing curves and semi-in planta experiments $[16,17]$. No standardized method exists for the process of screening microorganisms as potential biocontrol candidates for plant protection products, though general guidance is available for biocidal purposes [18]. Caution should be taken when assuming correlation between in vitro and field efficacy results as this process should be based directly on the pathosystem [2,19].

This study focused on the isolation and genomic characterization of prospective phages to target a known pathogen of onion: P.c. subsp. carotovorum. This is the first study providing the characterization of broad host range Podoviridae and Siphoviridae family bacteriophages infecting P. c. subsp. carotovorum and Pantoea spp. This study also provides an evaluation of a phage cocktail to protect onions against natural soft rot infection in three years of field trials using three different methods of application.

\section{Materials and Methods}

\subsection{Bacterial Isolates and Media}

Bacterial strains used in this study were isolated from soft rot tissue of onions growing in Northern Ireland and characterized to be Pectobacterium spp. Two isolated strains were identified as Pantoea spp. (Table S1). Bacteria were grown on crystal violet pectate media (CVP), with modifications reported previously [20]. Selected bacterial cultures were grown at $25^{\circ} \mathrm{C}$ for $24-48 \mathrm{~h}$ and were purified twice on nutrient agar (NA) CM0003 (Oxoid, Basingstoke, UK). Bacterial DNA was extracted using Maxwell ${ }^{\circledR} 16$ cell LEV DNA Purification kit (Promega, Madison, WI, USA) following the manufacturer's instructions and purified for 30-45 min using a Maxwell DNA Magnetic Particle Processor MX 3031 (Promega, Madison, WI, USA) using the cell purification program. DNA extracts were quantified using a NanoDrop 2000 (Thermo Scientific, Waltham, MA, USA), and the concentrations of bacterial DNA extracts adjusted to between $10-20 \mathrm{ng} / \mu \mathrm{L}$. Purified bacterial DNA was stored at $-20{ }^{\circ} \mathrm{C}$ until further analysis. Obtained bacterial DNA extracts were confirmed using real-time polymerase chain reaction (PCR), conventional PCR and/or recA sequencing as Pectobacterium spp., Pectobacterium atrosepticum (P. atrosepticum), P. c. subsp. carotovorum and Pantoea spp. (Table S1) using PCR amplification conditions and sequenced as reported previously [20].

To produce the liquid bacterial culture used for enrichment of bacteriophages, pure bacterial colonies were harvested and inoculated in nutrient broth (NB) containing peptone $(1 \mathrm{~g}$, Sigma Aldrich, St. Louis, MO, USA), yeast extract ( $0.5 \mathrm{~g}$, Oxoid, Basingstoke, UK), $\mathrm{NaCl}(0.25 \mathrm{~g}$, Thermo Fisher Scientific, Waltham, MA, USA), $\mathrm{K}_{2} \mathrm{HPO}_{4}$ (0.8 g, Thermo Fisher Scientific, Waltham, MA, USA) per $100 \mathrm{~mL}$, for $12-24 \mathrm{~h}$ at $25^{\circ} \mathrm{C}$ with $200 \mathrm{rpm}$ agitation and adjusted to ca. $10^{8} \mathrm{CFU} / \mathrm{mL}$ in NB (approx. $\left.\mathrm{OD} \mathrm{A}_{600}=0.2\right)$. 


\subsection{Isolation, Purification and Enrichment of Bacteriophages}

Bacteriophages were isolated from potato wastewater samples obtained from the Department of Agriculture, Environment and Rural Affairs Northern Ireland (DAERA) by filtration using a filtration unit and receiver flask Stericup ${ }^{\mathrm{TM}}$ Millipore Express $\mathrm{TM}^{\circledR}{ }^{\circledR}$ Plus $0.22 \mu \mathrm{m}$ (Merck, Darmstadt, Germany) connected to a general purpose vacuum pump (KNF Neuberger, ultimate vacuum 100 Mbar, flow rate $15 \mathrm{~L} / \mathrm{min}$ ). The volume of $40 \mathrm{~mL}$ of processing water sample was poured into the Steritop ${ }^{\mathrm{TM}}$ filter (Merck, Darmstadt, Germany) to obtain bacteriophage filtrate in the receiver flask.

For enrichment of bacteriophages, a volume of $5 \mathrm{~mL}$ of sterile $10 \times \mathrm{NB}$ containing peptone ( $20 \mathrm{~g}$, Sigma Aldrich, St. Louis, MO, USA), yeast extract (10 g, Oxoid, Basingstoke, UK), NaCl (5 g, Thermo Fisher Scientific, Waltham, MA, USA) and $\mathrm{K}_{2} \mathrm{HPO}_{4}(16 \mathrm{~g}$, Thermo Fisher Scientific, Waltham, MA, USA) per $200 \mathrm{~mL}$ was added to the Stericup ${ }^{\mathrm{TM}}$ Millipore Express $\mathrm{TM}^{\circledR}$ Plus filter receiver flask (Merck, Darmstadt, Germany) containing the filtered potato wastewater, followed by equal volumes $(2.5 \mathrm{~mL})$ of each bacterial liquid cultures $\left(c a .10^{8} \mathrm{CFU} / \mathrm{mL}\right)\left(\mathrm{OD} \mathrm{A}_{600}=0.2\right)$ (Table S1). The resulting solution (bacteriophage and bacteria) was incubated at $25^{\circ} \mathrm{C}$ with $200 \mathrm{rpm}$ agitation for $12-24 \mathrm{~h}$. Following that, an aliquot of $10 \mathrm{~mL}$ of the solution was transferred into a centrifuge tube and centrifuged at $\left(2000 \mathrm{rpm}, 5^{\circ} \mathrm{C}\right.$ ) for $5 \mathrm{~min}$. The supernatant which contained bacteriophages was filtered using a $10 \mathrm{~mL}$ syringe barrel fitted with a $0.22 \mu \mathrm{m}$ filter Millex ${ }^{\circledR}$ GV filter unit (Merck, Darmstadt, Germany). This bacteriophage filtrate was stored at $4{ }^{\circ} \mathrm{C}$ until use. The $100 \mu \mathrm{L}$ of filtrate was added to $900 \mu \mathrm{L}$ of sterile phosphate-buffered saline (PBS) buffer containing $\mathrm{NaCl}$ (1.6 g, Sigma Aldrich, St. Louis, MO, USA), $\mathrm{KCl}$ (0.04 g, Thermo Fisher Scientific, Waltham, MA, USA), $\mathrm{K}_{2} \mathrm{HPO}_{4}(0.22 \mathrm{~g}$, Sigma Aldrich, St. Louis, $\mathrm{MO}, \mathrm{USA})$ and $\mathrm{KH}_{2} \mathrm{PO}_{4}(0.04 \mathrm{~g}$, Thermo Fisher Scientific, Waltham, MA, USA) per $100 \mathrm{~mL}, \mathrm{pH} 7.4$. Ten-fold serial dilutions were made in PBS buffer pH 7.4 (Neat, $10^{-1}, 10^{-2}, 10^{-3}, 10^{-4}$ ) and subjected to plaque formation using the double layer agar method.

For plaque formation using the double layer agar method, the filtered potato wastewater was combined with equal volumes $(250 \mu \mathrm{L})$ of each liquid bacterial culture (Table S1) and $100 \mu \mathrm{L}$ of each bacteriophage in a ten-fold dilution and then incubated at $25^{\circ} \mathrm{C}$ for $20 \mathrm{~min}$ to allow the phage to adsorb to the bacteria. The $3-5 \mathrm{~mL}$ of top agarose $(\mathrm{TA})\left(37^{\circ} \mathrm{C}\right)$ containing peptone $(10 \mathrm{~g}$, Sigma Aldrich, St. Louis, MO, USA), yeast extract ( $5 \mathrm{~g}$, Oxoid, Basingstoke, UK), $\mathrm{NaCl}$ (2.5g, Thermo Fisher Scientific, Waltham, MA, USA), $\mathrm{K}_{2} \mathrm{HPO}_{4}(8 \mathrm{~g}$, Thermo Fisher Scientific, Waltham, MA, USA) and low gelling agarose (7.5 g, Sigma Aldrich, St. Louis, MO, USA) per litre was added to a $30 \mathrm{~mL}$ Sterilinßuniversal container (Thermo Fisher Scientific, Waltham, MA, USA). The container was capped quickly and mixed gently. The mixture was immediately poured onto the NA plates (CM0003, Oxoid, Basingstoke, UK) and left until the agarose solidified, and then incubated at $25^{\circ} \mathrm{C}$ for $24 \mathrm{~h}$.

Bacteriophages were purified through picking plaques obtained on NA plates (CM0003, Oxoid, Basingstoke, UK), using sterile pipette tips and eluting in $900 \mu \mathrm{L}$ of PBS buffer pH 7.4, following ten-fold dilutions. This step was repeated 3-5 times. To obtain bacteriophage lysate, double layer plates with phage plaques were subsequently re-suspended by adding $4 \mathrm{~mL}$ of PBS buffer at $\mathrm{pH} 7.4$. After $3 \mathrm{~h}$, harvested lysate was filter-sterilized using a $10 \mathrm{~mL}$ syringe barrel fitted (Thermo Fisher Scientific, Waltham, MA, USA ) with a $0.22 \mu \mathrm{m}$ filter Millex ${ }^{\circledR}$ GV filter unit (Merck, Darmstadt, Germany) and maintained in a $30 \mathrm{~mL}$ Sterilin ${ }^{\circledR}$ universal container (Thermo Fisher Scientific, Waltham, MA, USA) at $4{ }^{\circ} \mathrm{C}$. To determine the concentration of bacteriophage lysate, the volume of $10 \mu \mathrm{L}$ of lysate was added to $990 \mu \mathrm{L}$ of PBS buffer $\mathrm{pH}$ 7.4. Ten-fold serial dilutions were made in PBS buffer $\mathrm{pH}$ 7.4 and subjected to plaque formation for $24 \mathrm{~h}$ using the double layer agar method. The concentration of each bacteriophage lysate was expressed as plaque forming units (PFU/mL).

\subsection{TEM}

Bacteriophage lysate ( $\mathrm{ca} \cdot 10^{8}-10^{14} \mathrm{PFU} / \mathrm{mL}$ ) was concentrated and purified by centrifugation with modifications to the method previously described [21]. Modifications involved centrifugation at $\left(30,000 \times g, 4{ }^{\circ} \mathrm{C}\right)$ for each purification step and washing with $500 \mu \mathrm{L} 1 \mathrm{M}$ ammonium acetate, $\mathrm{pH} 7.4$ (Thermo Fisher Scientific, Waltham, MA, USA). The copper grids were placed on $10 \mu \mathrm{L}$ of pellet 
containing bacteriophages for $15 \mathrm{~min}$ to adsorb and then negatively stained using $4 \%$ ammonium molybdate (Sigma Aldrich, St. Louis, MO, USA) for $2 \mathrm{~min}$. The excess of liquid was removed using filter paper (Whatman, Munich, Germany). The grids were dried for $5 \mathrm{~min}$, then observed at $80 \mathrm{kv}$ using transmission electron microscope JEM-1400 TEM (JEOL, Peabody, MA, USA) at the Veterinary Sciences Division AFBI, Belfast.

\subsection{Screening Bacteriophages against Soft Rot Bacteria Species for Cocktail Formulation}

Four isolated bacteriophages were tested for virulence using a spotting assay and an overlay assay against 12 bacterial isolates that were isolated in Northern Ireland in the years 2016-2017 from soft rot onion tissue.

For the spotting assay, a total volume of $250 \mu \mathrm{L}$ of the liquid bacterial culture $\left(c a .10^{8} \mathrm{CFU} / \mathrm{mL}\right)$ was inoculated into TA $\left(5 \mathrm{~mL}, 37^{\circ} \mathrm{C}\right)$. After gentle vortexing of this mixture, it was poured into prepared NA (CM0003, Oxoid, Basingstoke, UK) plates and allowed to solidify at room temperature for $30 \mathrm{~min}$ to produce bacterial lawns. Phage lysate $\left(20 \mu \mathrm{L}\right.$, ca. $\left.10^{8} \mathrm{PFU} / \mathrm{mL}\right)$ was spotted using a pipette onto the TA layer, and left to dry at room temperature for $30 \mathrm{~min}$ following incubation at $25^{\circ} \mathrm{Cfor} 12 \mathrm{~h}$ and examination for inhibition zones.

For the overlay assay, phage lysate dilutions (ten-fold) $(100 \mu \mathrm{L})$ were mixed with $250 \mu \mathrm{L}$ of each bacteria isolate (Table S1) and then incubated for $20 \mathrm{~min}$ in $25^{\circ} \mathrm{C}$. The obtained ten-fold dilutions were combined with TA $\left(5 \mathrm{~mL}, 37^{\circ} \mathrm{C}\right)$, then poured into NA (CM003, Oxoid, Basingstoke, UK). The medium was allowed to solidify for $30 \mathrm{~min}$ at room temperature, after which the plates were incubated at $25^{\circ} \mathrm{C}$ for $24 \mathrm{~h}$ and then examined for plaque formation.

The efficiency of plating (EOP) of tested bacteriophages in overlay and spotting assays on each bacteria isolate was determined as the ratio of the titre of the phage on a given cell line/titre of phage on a maximum cell line calculated in PFU/mL after plating [22].

\subsection{DNA Extraction, Purification and DNA Sequencing}

The bacteriophage lysates were filter-purified using a $10 \mathrm{~mL}$ syringe barrel fitted with a $0.22 \mu \mathrm{m}$ filter Millex ${ }^{\circledR}$ GV filter unit (Merck, Darmstadt, Germany) and stored in a $30 \mathrm{~mL}$ Sterilin ${ }^{\circledR}$ universal container (Thermo Fisher Scientific, Waltham, MA, USA) at $4{ }^{\circ} \mathrm{C}$ prior to use. HTS was performed using the MiSeq ${ }^{\mathrm{TM}}$ sequencer (Illumina, San Diego, CA, USA) with v2 $2 \times 250$ sequencing reagents (Illumina, San Diego, CA, USA) following the manufacturer's instructions for denaturation of a $2 \mathrm{nM}$ library at AFBI Veterinary Sciences Division, Belfast with the modification to the method described previously [23].

\subsection{Genomic and Phylogenetic Analysis}

The obtained fastaq raw reads of each bacteriophage (the forward and reverse strands) were paired into one single read list. The quality was enhanced by trimming off the low-quality reads using BBDuk tool, errors corrected, normalized using BBnorm, chimeric and duplicate reads were removed using tools in Geneious Prime version 2019.1.3 (Biomatters Ltd., Auckland, New Zealand). Corrected sequences were assembled using de novo assembler and placed into scaffolds. Assembled genomes were compared with bacteriophages sequences available in GenBank (National Centre of Biotechnology Information, Bethesda, MD, USA) using blastn tool in Geneious Prime version 2019.1.3 (Biomatters Ltd., Auckland, New Zealand) software. Obtained bacteriophage genomes (partial and complete) were deposited in GenBank under accession numbers MN518139, MN509793, MN692199 and MN692200.

Phylogenetic analysis was performed to identify the taxonomic position of the bacteriophage genomes within Caudovirales order. Multiple alignments of four bacteriophages were performed using CLC Genomics Workbench 9.5.4 (Qiagen, Redwood City, CA, USA) with bacteriophage's reference capsid proteins available in GenBank including following genera of Siphoviridae: Chivirus (ATW62400.1, AZV00099.1, AXY84874.1), Nonagvirus (YP_009219975.1, YP_009216943.1), Myunavirus 
(ATS94104.1, YP_006906393.1), Seuratvirus (YP_009196799.1, YP_0091511949.1) and two unclassified genera (AZS06248.1) and (AZS06320.1). For two obtained Podoviridae bacteriophages the genomes were aligned with members of Phimunavirus (KT2401861.1, NC_031068), Phikmvvirus (ABY71003.1, YP_033345495.1), Teseptimavirus (KY124276.2, KY250035.1), N4-like virus (KY549659.1, KY514264.1 and NC_021772.1) and two further unclassified phages (NC_019911.2 and MK053931.1).

Bacteriophage genomes were mapped and open reading frames (ORFs) were predicted using SnapGene ${ }^{\circledR}$ (GSL Biotech LLC., Chicago, IL, USA). Further analysis of predicted ORFs gene products was conducted with the blastp (protein-protein BLAST) [24] tool using SnapGene®(GSL Biotech LLC., Chicago, IL, USA). The obtained genomes were also annotated for number of subsystems and coding sequences (CDS) with Rapid Annotations using Subsystems Technology (RAST) annotation scheme RASTtk pipeline version 2.0 [25] with threshold repeat region SEED at a minimum 95\% identity and minimum length $100 \mathrm{bp}$. CDS were predicted using Glimmer 3.0 and Prodigal with RAST [25]. The analysis of conserved domains in bacteriophage genomes was performed using conserved domains database (CDD) [26]. The presence of transfer RNAs were screened using rRNA-SEED and tRNA-trnascan with the use of RASTtk [25]. Detection of potential acquired antimicrobial resistance genes present in bacteriophage genomes was performed using ResFinder 3.2 [27] with identity threshold at $90 \%$ and minimum coverage $60 \%$. Screening for encoding virulence genes of human bacteria: Listeria, Staphylococcus aureus, Escherichia coli, Enterococcus and toxins was performed using Virulence Finder 2.0 [28] with identity threshold $90 \%$ and minimum coverage $60 \%$. Identification of genes involved in mycotoxin synthesis was performed using ToxFinder 1.0 [29] with the default setting option.

\subsection{Phage Cocktail Used in Field Trials}

For the cocktail of non-formulated bacteriophages, four lysates ( $\varphi$ MA11, $\varphi$ MA12, $\varphi$ MA13 and $\varphi$ MA14), were mixed with a ratio 1:1:1:1, with each phage lysate adjusted to be ca. $10^{8} \mathrm{PFU} / \mathrm{mL}$. The phage cocktail was stored at $4{ }^{\circ} \mathrm{C}$ until use. Phage cocktail for field trial application was formulated through enriching a volume of $1 \mathrm{~mL}$ of the formulated phage cocktail and $500 \mu \mathrm{L}$ of liquid bacterial suspension $\left(\mathrm{OD} \mathrm{A}_{600}=0.2\right.$ or approximately ca. $\left.10^{8} \mathrm{CFU} / \mathrm{mL}\right)$ in $800 \mathrm{~mL}$ of $\mathrm{NB}$ and made up to $1 \mathrm{~L}$ with sterile water. The mixture was incubated overnight at $25^{\circ} \mathrm{C}$ with agitation $(200 \mathrm{rpm})$. After overnight incubation, the phage cocktail was separated from the bacterial suspension by filtration using a Millipore Express TM ${ }^{\circledR}$ Plus $0.22 \mu \mathrm{m}$ filter (Merck, Darmstadt, Germany) and collected into a Millipore filter receiver flask (Merck, Darmstadt, Germany) connected to a general-purpose vacuum pump. The concentration of phage cocktail for field trial application was standardized to be ca. $10^{6}-10^{8} \mathrm{PFU} / \mathrm{mL}$. Phage cocktail was stored at $4{ }^{\circ} \mathrm{C}$ prior to field application.

\subsection{Planting Material}

Stuttgarter cultivar onion bulb seeds of UK origin were sourced from a commercial supplier in years 2016-2018 and planted in April each year. Onion bulbs were stored at $5{ }^{\circ} \mathrm{C}$ prior to use in the field trial.

\subsection{Treatments and Evaluation Methods Used in Field Trials}

Two application methods (immersion, and spraying) of phage cocktail on onions in the years 2016-2018 were used in the field trials with three treatments (spraying $(\mathrm{T} 1)$, spraying $_{(\mathrm{T} 2)}$, immersion (T3) and three controls (untreated $(\mathrm{C} 1)$, negative $(\mathrm{C} 2)$, positive $\left.{ }_{(\mathrm{C} 3)}\right)$ tested in three locations in Northern Ireland (Table 1). In each year, trials were performed in different locations to avoid transmission of pathogens and phages (Table 1).

During three years of trials, a $20 \times 6$ block statistical design was used (including 20 onions/plot, 120 onions/treatment, 120 onions/block). 
Table 1. Details of field trials performed in years 2016-2018.

\begin{tabular}{|c|c|c|c|c|c|c|c|}
\hline \multirow[b]{2}{*}{ Year } & \multirow[b]{2}{*}{ Location } & \multicolumn{6}{|c|}{ Number of Applications per Treatment $\times$ Volume [L] /Plot } \\
\hline & & $\begin{array}{l}\text { Spraying } \\
\text { (T1) } 1\end{array}$ & $\begin{array}{l}\text { Spraying } \\
\text { (T2) }^{2}\end{array}$ & $\begin{array}{c}\text { Immersion } \\
\text { (T3) }\end{array}$ & $\begin{array}{l}\text { Untreated } \\
\text { (C1) }\end{array}$ & $\begin{array}{l}\text { Negative } \\
\text { (C2) }\end{array}$ & $\begin{array}{l}\text { Positive } \\
\text { (C3) }^{6}\end{array}$ \\
\hline 2016 & Belfast, Co. Antrim, NI & $4 \times 1$ & $4 \times 1$ & $1 \times 2$ & NT & $1 \times 2$ & $1 \times 2$ \\
\hline 2017 & Crossnacreevy, Co. Down, NI & $4 \times 1$ & $4 \times 1$ & $1 \times 2$ & NT & $1 \times 2$ & $1 \times 2$ \\
\hline 2018 & Loughgall, Co. Armagh, NI & $4 \times 1$ & $4 \times 1$ & $1 \times 2$ & NT & $1 \times 2$ & $1 \times 2$ \\
\hline
\end{tabular}

${ }^{1}$ For spraying (T1), planted onions were sprayed with the phage cocktail starting from the first day of planting, and this continued once per week for the next four weeks at an application rate of $1 \mathrm{~L} /$ plot. $^{2}$ Spraying (T2) treatment involved spraying onions with phage cocktail two weeks after planting at an application rate of $1 \mathrm{~L} / \mathrm{plot}$, and this continued once per week for the four following weeks. Spraying was performed using a Knapsack spraying pump directly into the soil on rows with planted material (spraying $\mathrm{T}_{1}$ ) or visible onion foliage (spraying $\mathrm{T}_{\mathrm{T}}$ ). ${ }^{3}$ Treatment immersion $_{(\mathrm{T} 3)}$ was achieved by submerging onion bulb seeds in $2 \mathrm{~L}$ of phage cocktail for $24 \mathrm{~h}$ before planting. ${ }^{4}$ Untreated (C1) control plots received no phage or bacterial treatments throughout the experiment. ${ }^{5}$ For negative control (C2) onions were immersed in $2 \mathrm{~L}$ of NB and left to soak for $24 \mathrm{~h}$ before planting. ${ }^{6}$ As a positive control (C3), onions were immersed in $2 \mathrm{~L}$ of bacteria suspension ca. $10^{8} \mathrm{CFU} / \mathrm{mL}$. NT-not treated.

From 2016-2018, differences in emergence, soft rot frequency and yield after harvest (mass of bulbs and foliage) were recorded between the five treatments. Soft rot frequency was confirmed due to Pectobacterium spp. through isolation on CVP media [30], real-time PCR or/and recA gene sequencing using the method previously reported [20] (Table S1). Emergence was calculated as the number of plants planted that were growing approximately 7-8 weeks after planting (out of a total of 120 onions/treatment).

\subsection{Persistence of Phage Cocktail Treated Tubers in Field Trial 2016}

To supplement knowledge about bacteriophage persistence in treated onions for extended periods of time, onions harvested in 2016 were planted in the field trial in 2017 and assessed for emergence, soft rot frequency and yield. A $5 \times 6$ blocks statistical design was tested (including 5 onions/plot, 30 onions/treatment, 30 onions/block). Emergence was calculated as detailed previously (out of a total of 30 onions/treatment).

\subsection{Statistical Analysis}

Statistical analysis was carried out using GenStat ${ }^{\circledR}$ release 16.2 software (VSN International Ltd, Hemel Hempstead, UK). One-way analysis of variance (ANOVA) was used to compare efficacy of the treatments on yield, emergence and soft rot frequency on onions. Multiple comparisons were performed using Fisher's least significant difference (LSD).

\section{Results}

\subsection{Isolation, Purification and Identification of Bacteriophages}

Characterization using TEM of purified and titrated bacteriophage particles revealed four bacteriophages belonging to two families of the order Caudovirales: Podoviridae and Siphoviridae. Two of the detected bacteriophages belonged to the Podoviridae family (Figure 1A,B and Table 2). These had a short non-contractile tail ( $\varphi$ MA13) and a tail $11.22 \mathrm{~nm}$ length ( $\varphi$ MA14) (Table 2). Two bacteriophages were characterized as members of the Siphoviridae family (Figure 1C,D) and had icosahedral heads (50.1-58.7 $\mathrm{nm} \times 42.1-48.78 \mathrm{~nm}$ ) and flexible tails (223-227 nm) (Table 2). 


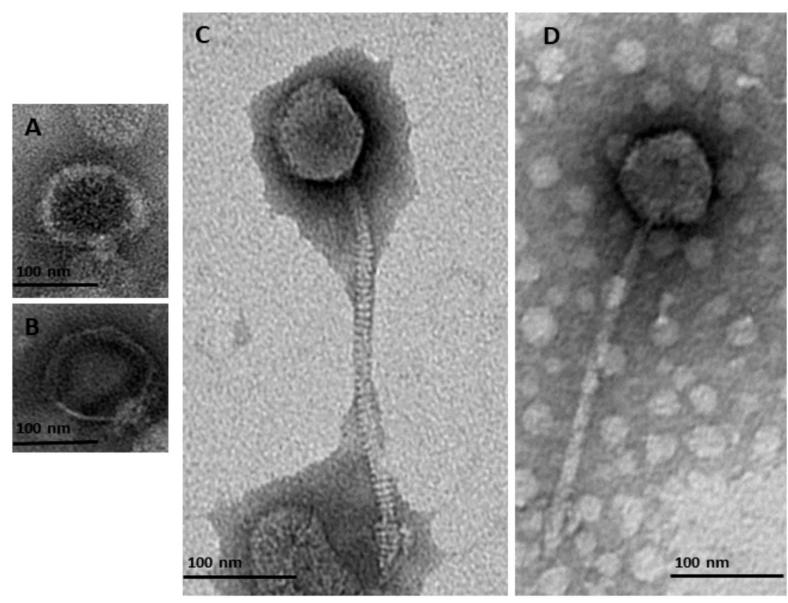

Figure 1. Transmission electron micrographs of negatively stained bacteriophages identified in this study from the order Caudovirales belonging to two families of Podoviridae (A) $\varphi$ MA13; (B) $\varphi$ MA14; and Siphoviridae (C) $\varphi$ MA12 (D) $\varphi$ MA11.

Table 2. Characteristics of bacteriophages isolated in this study.

\begin{tabular}{|c|c|c|c|c|c|c|c|c|}
\hline \multirow{2}{*}{$\begin{array}{l}\text { Accession } \\
\text { No. }\end{array}$} & \multirow[t]{2}{*}{ Phage ID } & \multicolumn{2}{|c|}{$\begin{array}{l}\text { Morphological } \\
\text { Characteristics }^{\text {a }}\end{array}$} & \multirow[t]{2}{*}{ Order $^{a, b}$} & \multirow[t]{2}{*}{ Family $^{a, b}$} & \multirow[t]{2}{*}{ Subfamily/Genus ${ }^{b}$} & \multirow[t]{2}{*}{$\mathrm{Id}^{\mathrm{b}}(\%)$} & \multirow[t]{2}{*}{$\begin{array}{l}\text { Genome } \\
\text { Size (bp) }\end{array}$} \\
\hline & & Head (nm) & Tail (nm) & & & & & \\
\hline MN518139 & $\varphi \mathrm{MA} 11$ & $50.1 \times 42.1$ & 223.4 & Caudovirales & Siphoviridae & Chivirus & 70 & 55,830 \\
\hline MN692199 & $\varphi \mathrm{MA} 12$ & $58.7 \times 48.7$ & 227.9 & Caudovirales & Siphoviridae & Chivirus & 65 & 58,573 \\
\hline MN509793 & $\varphi \mathrm{MA} 13$ & $67.1 \times 72.1$ & $\mathrm{~nm}$ & Caudovirales & Podoviridae & Autographivirinae & 76 & 42,464 \\
\hline MN692200 & $\varphi \mathrm{MA} 14$ & $57.3 \times 55.1$ & 11.22 & Caudovirales & Podoviridae & Autographivirinae & 71 & 10,019 \\
\hline
\end{tabular}

${ }^{a}$ Features identified by TEM; ${ }^{b}$ Features annotated by blastp is $\%$ identity of nucleotide sequence with the closest phage by nucleotide sequence; nm-not measured tail.

\subsection{Genomic Characterization of Bacteriophages}

BLAST analysis of $\varphi$ MA13 and $\varphi$ MA14 bacteriophages revealed these have a taxonomic rank of Podoviridae family of unclassified Autographivirinae subfamily (Table 2). In phylogenetic analysis of major capsid proteins phages $\varphi$ MA13 and $\varphi$ MA14 grouped in two separate clusters. Phage $\varphi$ MA14 clustered separately in the group of several unclassified bacteriophages (Pectobacterium phage Arno160 and Yersinia phage 80-18) (Figure 2A). Bacteriophage $\varphi$ MA14 grouped in separate cluster with unclassified subfamily Pectobacterium phage PP2 (Figure 2A).

BLAST analysis [24] of $\varphi$ MA11 and $\varphi$ MA12 bacteriophages revealed the highest similarity to Siphoviridae family of Chivirus genera (Table 1). Phages $\varphi$ MA11 and $\varphi$ MA12 grouped in two main clusters with Siphoviridae family bacteriophages obtained from GenBank in phylogenetic analysis of major capsid proteins. Separate sub-clusters grouped Salmonella Chivirus phages (KFS-SEI, Season12 and Siskin) and phages $\varphi$ MA11, $\varphi$ MA12 distinct from other subfamilies (Figure 2B).

For assembled genomes of Siphoviridae bacteriophages ORFs were identified to be 55 ( $\varphi$ MA11), 61 ( $\varphi$ MA12) and 52 for Podoviridae $\varphi$ MA13. The conserved domains were identified in 32 ORFs of $\varphi \mathrm{MA} 11,30$ of $\varphi$ MA12 and 18 of $\varphi$ MA13 (Table S2).

Analysis of $\varphi$ MA11 genome revealed the presence of 17 orphan genes (ORFans) with no reliable identity found in GenBank database (E-values > 0.001), 20 ORFs for which functions were predicted and 18 hypothetical proteins (Figure 3). 
A

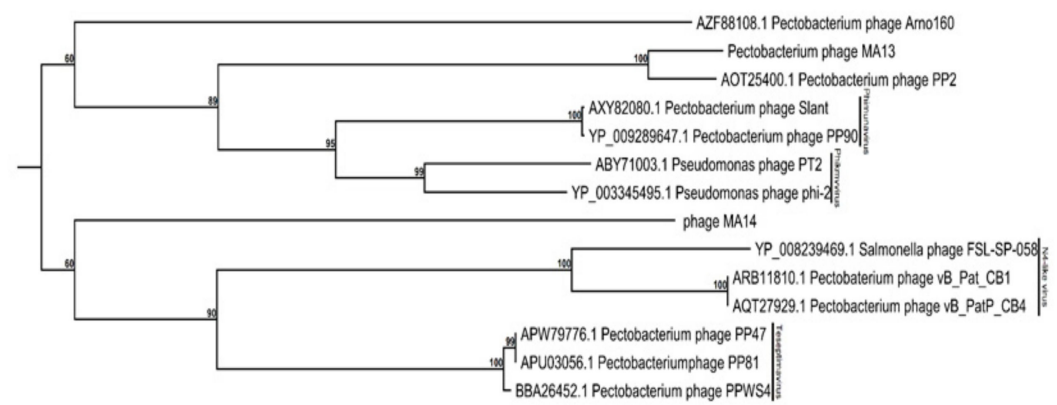

B
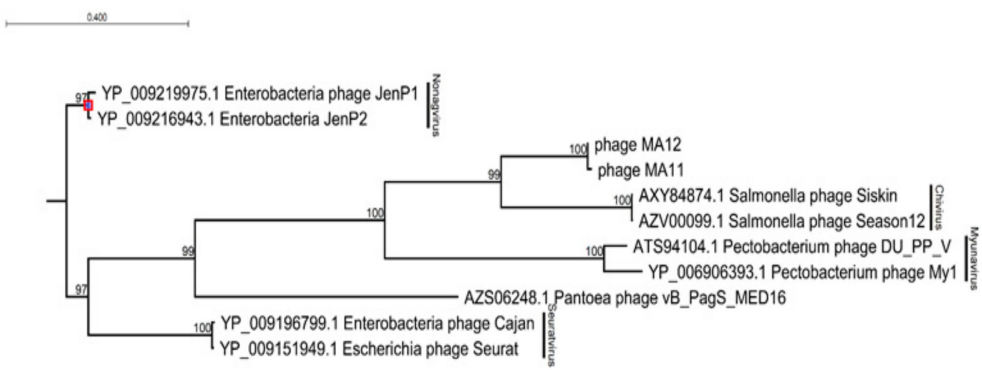

Figure 2. Maximum-likelihood phylogenetic analysis of major capsid proteins of phages isolated in this study constructed using a neighbor-joining method with protein substitution model Dayhoff (PAM) using CLC Genomic Workbench 9.5.4. (A) Members of Podoviridae family phages. (B) Members of Siphoviridae family phages. For phages obtained from GenBank capsid proteins accession numbers followed by phages names; phages isolated in this study: phage MA11, phage MA12, phage MA13 and phage MA14. Bootstrap probabilities values $<50 \%$ were collapsed.

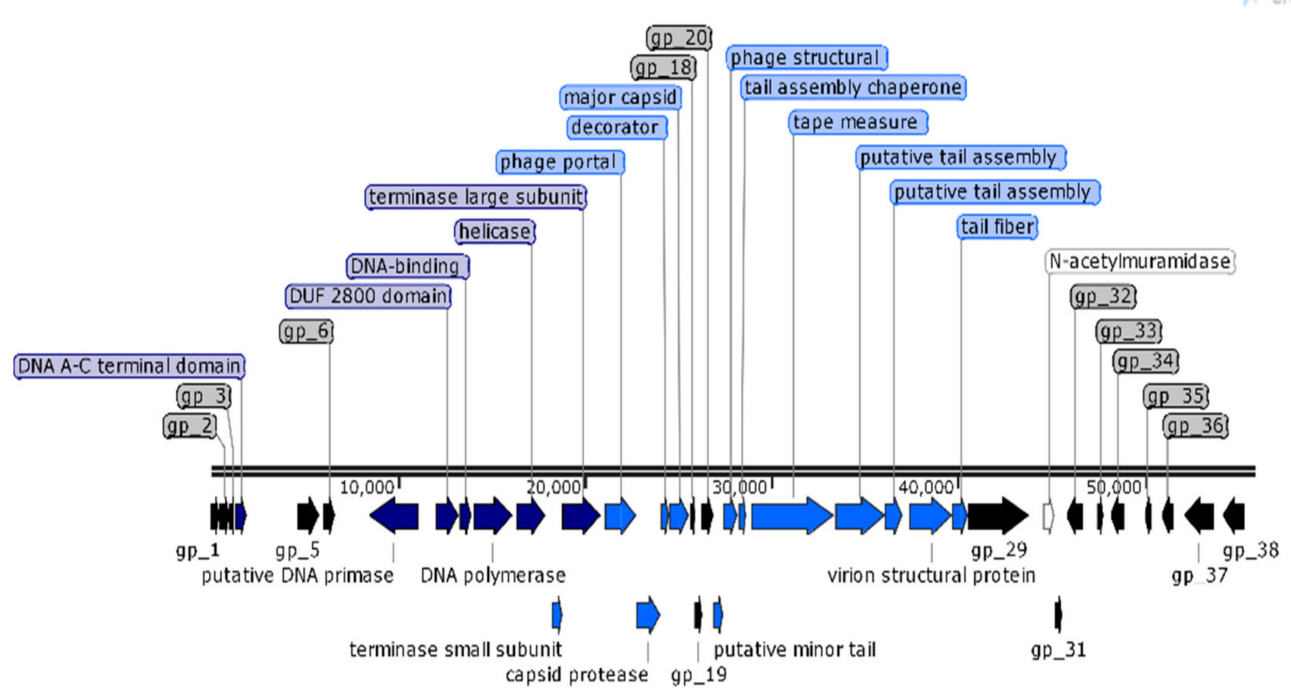

Figure 3. Structural and functional annotation map of $\varphi$ MA11 bacteriophage (55,830 bp) for 55 open reading frames (ORFs) encoding proteins. ORFs coding for the following proteins: hypothetical (black), structural proteins (light blue), proteins for phage replication and lifecycle (dark blue), lysis (white).

For $\varphi$ MA12 genome nine ORFans were identified with ( $E$-values $>0.001), 22$ ORFs with predicted functions and 29 hypothetical proteins (Figure 4). 


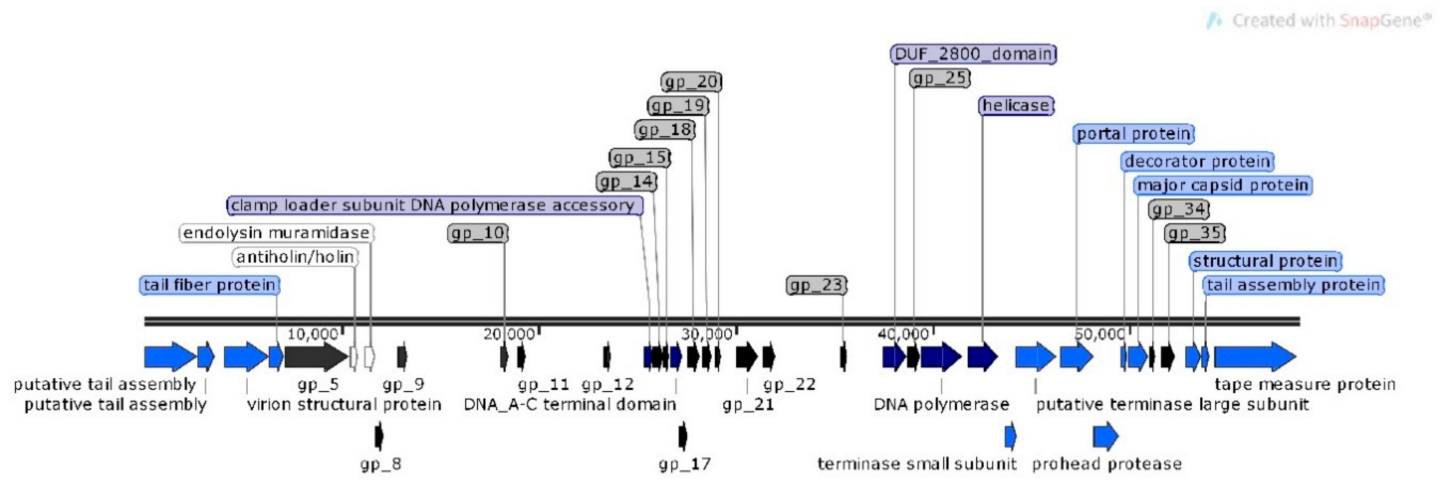

Figure 4. Structural and functional annotation map of $\varphi$ MA12 bacteriophage (58,735 bp) for 60 ORFs encoding proteins. ORFs coding for the following proteins: hypothetical (black), structural proteins (light blue), proteins for phage replication and lifecycle (dark blue), lysis (white).

For bacteriophage $\varphi$ MA13 from 51 identified ORFs, 20 have predicted functions, 11 hypothetical proteins and 20 (ORFans) with no reliable functions identified.

The analysis of $\varphi$ MA11, $\varphi$ MA12 and $\varphi$ MA13 genomes revealed clusters of proteins involved in DNA replication, recombination, repair and suppression of the host such as: DNA polymerases ( $\varphi$ MA11; $\varphi$ MA12; $\varphi$ MA13), DNA helicases ( $\varphi$ MA11; $\varphi$ MA12; $\varphi$ MA13), ssDNA-binding proteins ( $\varphi$ MA11; $\varphi$ MA12), terminases small and large subunits ( $\varphi$ MA11, $\varphi$ MA12, $\varphi$ MA13), DNA A-C terminal domains ( $\varphi$ MA11; $\varphi$ MA12) and DUF 2800 domain (MA11; $\varphi$ MA12) (Figures 3-5). Clusters of additional proteins involved in these processes has been predicted in Podoviridae phage $\varphi$ MA13 such as putative DNA maturase, protein gp3, ATP-dependent DNA ligase, DNA exonuclease, DNA endonuclease and RNA polymerase (Figure 5).

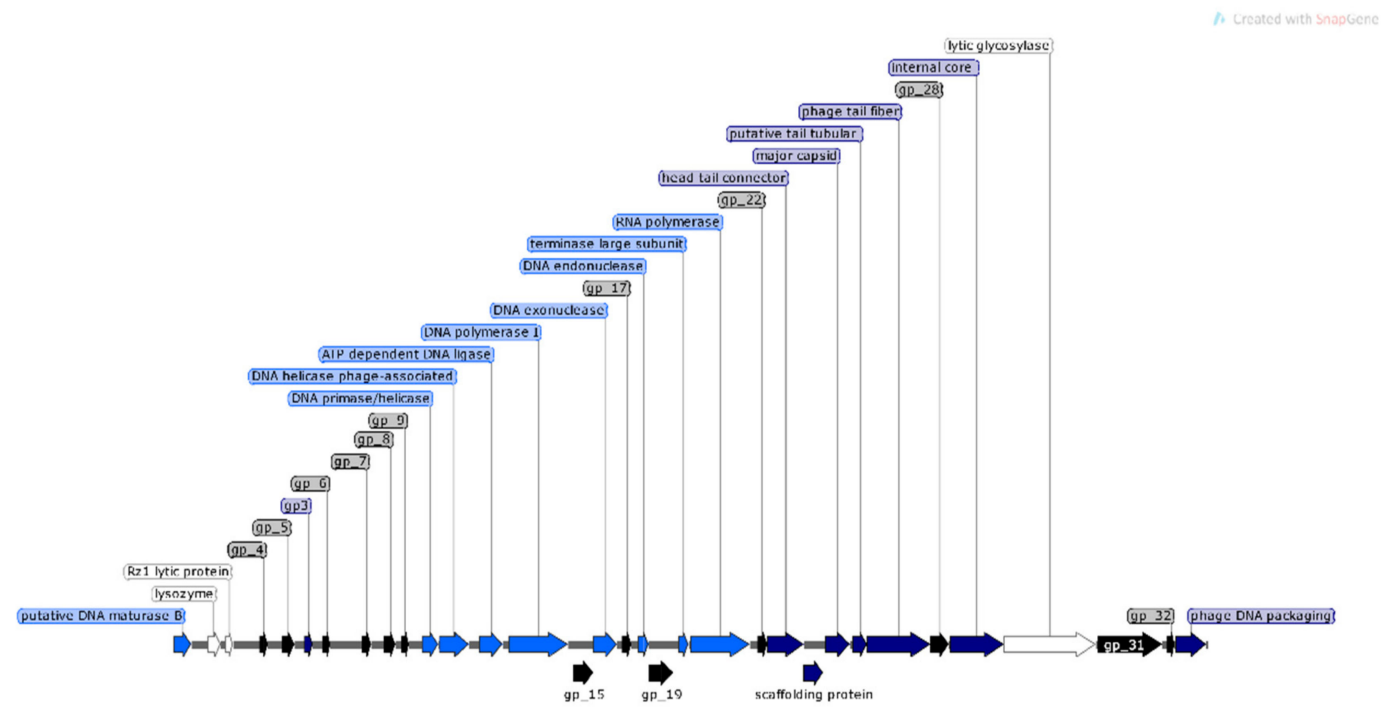

Figure 5. Structural and functional annotation map of $\varphi$ MA13 bacteriophage (42,464 bp) for 51 ORFs encoding proteins. ORFs coding for the following proteins: hypothetical (black), structural proteins (light blue), proteins for phage replication and lifecycle (dark blue), lysis (white).

Bacteriophages $\varphi$ MA11 and $\varphi$ MA12 genomes encode endolysin and holin proteins involved in lysis process: N-acetylmuramidase (DUF 3380 superfamily protein cl13324) ( $\varphi$ MA11; $\varphi$ MA12) and antiholin/holin protein ( $\varphi$ MA12) (Figures 3 and 4). Bacteriophage $\varphi$ MA13 encodes three proteins related to lysis module such as: lysozyme, Rz1 lytic protein and lytic glycosylase (Figure 5).

Gene products predicted to be involved in virion structure and assembly were organized as a discrete module involving phage portal ( $\varphi$ MA11; $\varphi$ MA12), major capsid ( $\varphi$ MA11; $\varphi$ MA12; MA13), 
phage structural protein ( $\varphi$ MA11; $\varphi$ MA12), capsid protease ( $\varphi$ MA11), prohead protease ( $\varphi$ MA12), decorator ( $\varphi$ MA11; $\varphi$ MA12), tail assembly chaperone ( $\varphi$ MA11), tape measure ( $\varphi$ MA11; $\varphi$ MA12), putative tail assembly ( $\varphi$ MA11), tail fiber ( $\varphi$ MA11; MA13), and virion structural proteins ( $\varphi$ MA11) (Figures 3-5). For bacteriophage $\varphi$ MA13 four further structural proteins has been predicted including: head tail connector, putative tail tubular, internal core and phage DNA packaging (Figure 5).

RASTtk pipeline analysis using mRNA and tRNAscan-SE did not reveal the presence of RNAs in bacteriophages genomes (Tables S3 and S4). Virulence Finder, ResFinder 3.1 and ToxFinder revealed no genes that encode antibiotic resistance, toxins or taking a part in synthesis of mycotoxins (Table S3).

\subsection{Phage Cocktail Formulation}

Clear plaque formation in overlay assays and/or lysis of biofilm in spot assays revealed that all phages could lyse Pectobacterium spp. isolates, while $\varphi$ MA12 and $\varphi$ MA14 lysed Pantoea spp. isolates (Table 3).

Table 3. Host range of bacteriophages used in this study.

\begin{tabular}{|c|c|c|c|c|c|c|}
\hline \multirow{2}{*}{ Isolate Id } & \multirow{2}{*}{$\begin{array}{l}\text { County } \\
\text { Location }\end{array}$} & \multirow{2}{*}{$\begin{array}{l}\text { Year of } \\
\text { Isolation }\end{array}$} & \multicolumn{4}{|c|}{ EOP of Bacteriophages ${ }^{1}$} \\
\hline & & & $\varphi$ MA11 & $\varphi$ MA12 & $\varphi$ MA13 & $\varphi$ MA14 \\
\hline \multicolumn{7}{|l|}{ Pectobacterium spp. } \\
\hline $\mathrm{OM} / \mathrm{Z}-1 / 15$ & Armagh & 2015 & $(1)$ & (1) & (1) & - \\
\hline $\mathrm{OM} / \mathrm{Z}-4 / 15$ & Armagh & 2015 & (1) & - & - & - \\
\hline $\mathrm{OM} / \mathrm{Z}-5 / 15$ & Armagh & 2015 & $1 *$ & 0.01 & $0.001 *$ & 0.04 \\
\hline $\mathrm{OM} / \mathrm{Z}-1 / 10 / 15$ & Armagh & 2015 & - & - & - & 0.5 \\
\hline $\mathrm{OM} / \mathrm{Z}-2 / 10 / 15$ & Armagh & 2015 & - & - & - & 0.1 \\
\hline $05 \mathrm{~A} / 16$ & Down & 2016 & $(1)$ & - & (1) & $(1)$ \\
\hline 05B/16 & Down & 2016 & - & - & (1) & (1) \\
\hline $06 / 16-1$ & Down & 2016 & (1) & (1) & (1) & (1) \\
\hline O7/16 & Antrim & 2016 & - & - & - & - \\
\hline O7B/16 & Antrim & 2016 & - & - & - & - \\
\hline O17A/16 & Antrim & 2016 & - & - & - & - \\
\hline $\mathrm{O} 12 / 16$ & Antrim & 2016 & - & - & - & - \\
\hline O17B/16 & Antrim & 2016 & 0.003 & - & - & - \\
\hline O7C/16 & Antrim & 2016 & 0.01 & 0.01 & - & - \\
\hline $015 / 16$ & Antrim & 2016 & - & 0.1 & - & - \\
\hline \multicolumn{7}{|l|}{ Pantoea spp. } \\
\hline $\mathrm{O} 21 / 16$ & Antrim & 2016 & - & $1^{*}$ & - & - \\
\hline $\mathrm{O} 21 \mathrm{~B} / 16$ & Antrim & 2016 & - & - & - & $1^{*}$ \\
\hline
\end{tabular}

${ }^{1}$ Efficiency of plating (EOP) of bacteriophages tested in this study in overlay assay determined as the titre of the phage on a given cell line/titre of phage on a maximum cell line. Asterisks $\left(^{*}\right)$ indicated denominator cell line; '-' no plaque obtained by overlay and spotting assays. Value in brackets indicated titer obtained in spotting assay.

\subsection{Evaluation of Efficacy of the Phage Cocktail in Vivo}

A protective effect against soft rot development was observed in all three years of field trials that evaluated phage cocktail-treated onions. Plants treated through spraying treatments (T1) and, (T2), and the immersion treatment ${ }_{(\mathrm{T} 3)}$ had significantly fewer soft rot symptoms in comparison to controls (Table 4).

In the 2016 field trial, there was no significant influence of the phage cocktail through any of the three treatments on the emergence or yield (mass of bulbs, or mass of foliage) after harvest in comparison to the untreated control as determined by one-way-ANOVA. There were significantly fewer $(p<0.05)$ soft rot symptoms in the phage cocktail treated onions, irrespective of application method (both spraying methods and the immersion method) in comparison to the untreated control according to Fisher's LSD test (Table 4).

There was no significant difference between the emergence of phage cocktail treated plants and untreated plants (control) in the 2017 field trial (Table 4). In comparison to untreated onions, there was a significantly higher onion yield (i.e., higher bulb and foliage mass) in the immersion treatment compared with the positive control (Table 4). Significant differences were obtained from harvested onions in terms of the incidence of soft rot $(p<0.05)$, with less soft rot in the spraying ((T1), (T2) $)$ and 
immersion (T3) treatments than in the untreated onions and positive control plants according to a Fisher's LSD test.

Table 4. Mean values of onions treatments assessed in field trials 2016-2018.

\begin{tabular}{|c|c|c|c|c|c|c|c|c|c|c|c|c|}
\hline \multirow{2}{*}{$\begin{array}{c}\text { Treatment } \\
\text { Year }\end{array}$} & \multicolumn{3}{|c|}{ Emergence $^{4}(\%)$} & \multicolumn{3}{|c|}{ Bulbs Mass ${ }^{5}$ (g) } & \multicolumn{3}{|c|}{ Foliage Mass ${ }^{6}$ (g) } & \multicolumn{3}{|c|}{ Disease $^{7}(\%)$} \\
\hline & $2016^{1}$ & $2017^{2}$ & $2018^{3}$ & $2016^{1}$ & $2017^{2}$ & $2018^{3}$ & $2016^{1}$ & $2017^{2}$ & $2018^{3}$ & $2016^{1}$ & $2017^{2}$ & $2018^{3}$ \\
\hline \multicolumn{13}{|c|}{ Means } \\
\hline Spraying $_{(\mathrm{T} 1)} 8$ & $54.2 \mathrm{a}$ & $91.7 \mathrm{a}$ & $86.7 \mathrm{a}$ & $642 a$ & $2270 \mathrm{~b}$ & $2040 a$ & $282 a$ & $1312 b$ & $881 \mathrm{ab}$ & $3.3 \mathrm{a}$ & $0 \mathrm{a}$ & $1.7 \mathrm{~b}$ \\
\hline Spraying (T2) 9 & $72.5 \mathrm{a}$ & $95.0 \mathrm{a}$ & $70.8 b$ & $819 a$ & $1988 \mathrm{bc}$ & $1242 b$ & $481 \mathrm{a}$ & $1526 a b$ & $458 \mathrm{bc}$ & $3.3 a$ & $0 \mathrm{a}$ & $0 \mathrm{c}$ \\
\hline Immersion (T3) 10 & $63.3 a$ & $90.8 \mathrm{a}$ & $82.5 \mathrm{ab}$ & $466 a$ & $3056 a$ & $1399 b$ & $222 a$ & $1696 a$ & $585 \mathrm{ab}$ & $3.3 a$ & $0 \mathrm{a}$ & $2.5 \mathrm{~b}$ \\
\hline Untreated $_{(\mathrm{C} 1)} 11$ & $54.2 \mathrm{a}$ & $85.0 \mathrm{a}$ & $55.0 \mathrm{c}$ & $642 a$ & $2383 b$ & $702 c$ & $245 a$ & $624 c$ & $301 c$ & $18.3 b$ & $10.0 \mathrm{~b}$ & $5.0 \mathrm{~b}$ \\
\hline Negative $_{(\mathrm{C} 2)} 12$ & $59.2 a$ & $90.0 \mathrm{a}$ & $78.3 \mathrm{ab}$ & $561 \mathrm{a}$ & $1608 c$ & $1587 \mathrm{ab}$ & $342 \mathrm{a}$ & $795 c$ & $900 a$ & $15.8 b$ & $12.5 b$ & $10.8 \mathrm{a}$ \\
\hline Positive $_{(\mathrm{C} 3)^{13}} 13$ & NT & $39.2 b$ & $25.3 \mathrm{~d}$ & NT & $324 d$ & $313 d$ & NT & $249 d$ & $203 c$ & NT & $13.3 b$ & $1.8 \mathrm{~b}$ \\
\hline
\end{tabular}

${ }^{1}$ Field trial performed in Belfast, Co. Antrim, Northern Ireland, UK; ${ }^{2}$ Field trial performed in Crossnacreevy, Co. Down, Northern Ireland, UK; ${ }^{3}$ Field trial performed in Loughgall, Co. Armagh, Northern Ireland, UK; ${ }^{4}$ Percentage emergence $(\% \mathrm{Em})=$ number of plants assessed $\times 100 \% /$ number of plants planted; ${ }^{5}$ mass of onion bulbs harvested; ${ }^{6}$ mass of onion foliage harvested; ${ }^{7}$ percentage of soft $\operatorname{rot}(\% \mathrm{Sr})=$ number of plants with soft rot symptoms $\times 100 \% /$ total number of plants emerged; ${ }^{8}$ onions sprayed with phage cocktail from first day of planting for four weeks; ${ }^{9}$ onions sprayed with phage cocktail after first four weeks; ${ }^{10}$ onions pre-treated with phage cocktail before planting; ${ }^{11}$ onions not pre-treated before planting; ${ }^{12}$ onions pre-treated with NB before planting; ${ }^{13}$ onions pre-treated with artificial inoculum of bacteria $\left(c a .10^{8} \mathrm{CFU} / \mathrm{mL}\right)$ before planting. Treatment means that do not share the same letter $(\mathrm{a}, \mathrm{b}, \mathrm{c}$, and d) within each column are significantly different according to Fisher's Least significant difference at $p<$ 0.05 ; NT-not tested.

For the field trial in 2018, significant differences $(p<0.001)$ were recorded in terms of emergence, yield (of bulbs and foliage) and soft rot symptom frequency between treatments (Table 4). A Fisher's LSD test showed a significantly higher numbers of plants for all treatments when compared to the untreated and positive control ( $p<0.05)$. The yield (mass) of onions bulbs using the spraying (T2) and immersion $_{(\mathrm{T} 3)}$ treatments were not significantly different from the untreated plants (Table 4). Plants treated with phage cocktail showed significantly fewer soft rot disease symptoms in comparison to the positive or negative controls (Table 4).

\subsection{Persistence Trial of Bacteriophages in Phage Cocktail Treated Onions}

The persistence experiment in 2017 revealed a significant difference between emergence of phage cocktail treated plants (treated in 2016) using both application methods and untreated control plants (Table 5). Significant differences were recorded between soft rot frequency of treated plants with phage cocktail for all three treatments and untreated control plants by ANOVA $(p<0.05)$. Soil drench and foliage application treatments with the phage cocktail significantly increased bulb and foliage mass compared with the untreated control (Table 5).

Table 5. Means of treatments in the persistence trial.

\begin{tabular}{|c|c|c|c|c|}
\hline Treatment & Emergence ${ }^{5}(\%)$ & Soft $\operatorname{Rot}^{6}(\%)$ & Mass of Bulbs ${ }^{7}(\mathrm{~g})$ & Mass of Foliage ${ }^{8}(\mathrm{~g})$ \\
\hline \multicolumn{5}{|c|}{ Means } \\
\hline Spraying $_{(\mathrm{T} 1)}{ }^{1}$ & $93.3^{* *}$ & $3.3 *$ & $749 *$ & $807^{*}$ \\
\hline Spraying $_{(\mathrm{T} 2)} 2$ & $80.0 * *$ & $3.3 *$ & $541 *$ & $666^{*}$ \\
\hline Immersion $_{(\mathrm{T} 3)^{3}}{ }^{3}$ & 30 & $3.3^{*}$ & 346 & 314 \\
\hline Control (Untreated) ${ }^{4}$ & 36.7 & 30 & 314 & 288 \\
\hline
\end{tabular}

${ }^{1}$ Onions sprayed with phage cocktail in field trial 2016 starting from first day of planting and continued for the four following weeks at an application rate $1 \mathrm{~L} /$ plot and planted and assessed in $2017 ;{ }^{2}$ Onions sprayed with phage cocktail in field trial 2016 starting for four following weeks at an application rate $1 \mathrm{~L} / \mathrm{plot}$ (approximately 2 weeks after planting) and planted in $2017 ;^{3}$ The onion bulbs immersed in field trial 2016 in $2 \mathrm{~L}$ of phage cocktail for $24 \mathrm{~h}$ before planting and planted in 2017; ${ }^{4}$ Untreated onions with phage cocktail and bacteria growing in field trial 2016 and planted in 2017; ${ }^{5}$ Percentage emergence $=$ number of plants assessed $\times 100 \%$ / number of plants planted; ${ }^{6}$ Percentage of soft rot $=$ number of plants with soft rot symptoms $\times 100 \% /$ total number of plants tested; ${ }^{7}$ Mass of onions bulbs harvested; ${ }^{8}$ Mass of onions foliage harvested. Asterisk indicates a significant difference between the phage-based cocktail formulation treatments and control treatment (untreated) according to Fisher's least significant difference at $p<0.05\left(^{*}\right)$ and $p<0.001\left(^{* *}\right)$. 


\section{Discussion}

SRP (mainly Pectobacterium and Dickeya) species are the main causes of soft rot disease [31], and therefore this study focused on isolation of prospective phages to target Pectobacterium spp. (i.e., P. c. subsp. carotovorum). Interestingly, two of the isolated bacterial strains from onion soft rot tissue were identified as Pantoea spp., with one showing the most similarity by BLAST to Pantoea agglomerans (Pa. agglomerans) and the second to Pantoea dispersa. Pa. agglomerans is known to be endophytic in plants [32], but has been reported to cause soft rot of onions previously [33,34] Therefore, four phages were tested against these two isolated Pantoea spp., and could also serve as an indicator of the ability of the phages to infect a broad range of other closely related plant pathogenic bacteria. The vast majority of SRP bacteriophages (infecting Pectobacterium and Dickeya) tested for biocontrol applications belong to Podoviridae and Myoviridae families [35], with the Podoviridae bacteriophages infecting strains of P. c. subsp. carotovorum [12], P. atrosepticum [17,36], Pectobacterium parmentieri [37,38], and Dickeya solani (D. solani) [39]. One of the bacteriophages isolated and tested belongs to the Podoviridae family, and has a host range that includes P. c. subsp. carotovorum and Pantoea sp. Thus far, two bacteriophage phiKMV-like viruses of Podoviridae family have been characterized as infecting Pa. agglomerans strains of potato origin $[40,41]$.

In 2017, a new genus of Autographivirinae subfamily phages was proposed and reported as having potential for biocontrol applications [42]. The phage PP2 infecting P. c. subsp. carotovorum isolated from Chinese cabbage showed significant genetic distinction to other bacteriophages of Autographivirinae subfamilies [42]. In this study, bacteriophage $\varphi$ MA13 showed high similarity to phage PP2 in a phylogenetic analysis based on the genes related to major capsid protein and genome composition. Similar to previous findings of Podoviridae bacteriophages virulent against SRP [12,17,37,38], phage $\varphi$ MA13 contains genes encoding proteins involved in bacteria cell lysis and host suppression, and lacked proteins encoding for toxins or bacterial resistance. This bacteriophage could therefore be safely used for phage cocktail formulation.

Siphoviridae is the most abundant bacteriophage family within the Caudovirales order, which infects a broad range of Enterobacteriaceae species such as E. coli, Serratia, Bacillus, Pseudomonas, and Klebsiella spp. [41]. Although the virulence of this bacteriophage family against SRP or Pantoea spp. has not been frequently described in scientific literature, the family has been reported to infect $P$. $c$. subsp. carotovorum such as $\varphi$ My1 [43], Pectobacterium phage DU_PP_V [44], D. solani ( $\varphi$ CIM1) [39] and $P a$. agglomerans [41]. It has been indicated that some Siphoviridae bacteriophages could transmit generalized transduction which might be a threat for phage therapy due to resistance gene transfer between bacteria and phages $[45,46]$. Genomic analysis of two of the examined Siphoviridae phages did not indicate bacterial host homologs mRNA/tRNA $(E<0.001)$ that could indicate lysogenic lifecycle and transduction abilities. Moreover, conserved domain analysis indicated that lysis, replication and suppression of the host modules are well conserved within phages $\varphi$ MA11 and $\varphi$ MA12 (Table S3). Bacteriophage $\varphi$ MA11 was the most virulent against several P. carotovorum isolates tested in this study and phage $\varphi \mathrm{MA} 12$ has the broad host range within P. carotovorum and Pantoea sp. Interestingly, the protein DUF 2800 domain of both $\varphi$ MA11 and $\varphi$ MA12 bacteriophages was predicted by CDD analysis to encode a sequence of Cas4 protein (Cas4_I-A_I-B_I-C_I-D_II-B super family c100641) (Table S3) belonging to a clustered regularly interspaced short palindromic repeats-CRISPR associated system (CRISPR-Cas). CRISPR-Cas system is a well explored acquired immunity defense system of bacteria and archaea against other genetic materials such as plasmids and bacteriophages, which prevent against infection [47]. However, bacteriophages might evade immunity and use anti-CRISPR-Cas proteins such as Cas4 protein to infect bacteria $[48,49]$.

The persistence of bacteriophage treatments in crops over multiple growing seasons has not been explored in the field, though evidence exists regarding the persistence of SRP bacteriophages on potato tubers or leaves in vitro [13]. In this study, the efficacy of the phage cocktail appeared to be carried over to the year after treatment. These findings might indicate that bacteriophages like other viruses (i.e., 
potato virus $Y$ ) can be translocated and survive within plants over time [50]. The evidence presented here suggests that these findings should be investigated further.

Phage cocktail formulations containing several phages have been found to protect plants against the plant pathogenic bacterial species Erwinia amylovora, Xanthomonas campestris pv. vesicatoria, Xanthomonas axonopodis pv. citri, Xanthomonas citrumelo, Ralstonia pseudosolanacearum and Dickeya spp. in bioassay experiments [51]. By contrast, a formulation of a single bacteriophage efficacious against $D$. solani has been reported with limited success to control soft rot disease in field conditions [11]. In this study, in vivo experiments under field conditions showed that there is potential to use a phage cocktail to protect onions against the symptoms of soft rot (most likely caused by P. c. subsp. carotovorum) using spraying $_{(\mathrm{T} 2)}$, which was efficacious in three growing seasons. The other two treatments: spraying (T2) and immersion $(\mathrm{T} 3)$, were efficacious in two years of trials. Moreover, there was a significant difference in 2018 between spraying from the first day of planting (T1) and spraying only from four weeks after planting (T2). As inconsistency of biological control formulations has been shown previously, with a wide range of factors thought to influence this inconsistency [14], including variability of treatments caused by bacteriophages and their interaction in the cocktail (i.e. through synergy) [52]. Four of the fifteen strains of Pectobacterium could not be controlled in vitro using any of the bacteriophages tested (Table 3). All of these resistant strains were from Co. Antrim. Despite this finding, results from the field trials showed that the bacteriophage cocktail was efficacious at controlling soft rot of onions. This result supports previous studies [2,19] cautioning on extrapolating results from in-vitro studies to in field conditions. This study did not investigate synergy or inter-bacteriophage effects, and therefore it is difficult to assess which bacteriophages act as potential donors (enzymes producing phages which improve adsorption rate of other phages) with their recipient (phage which is benefiting from the enzyme) bacteriophages in the cocktail [52]. Therefore, these treatments should be further optimized (e.g., by calculating optimal concentration of each bacteriophage, and testing the optimal intensity of applications and synergy) during future investigations.

The spraying (T2) method was the most effective during three growing seasons; however, optimization of the immersion (T3) treatment would be the most beneficial from a practical point of view for the growers as this could be used for pre-treatment of onion seeds before planting reducing the need for specialist applications in the field. Further efficiencies could be made to the phage production process by replacing the nutrient broth stage for building up sufficient numbers of phages and purification.

This study was not comprehensive, as it did not carry out tests of phage kinetics in vitro (suppression and stability) and focused more on the ability of the phages to control soft rot in field settings. Therefore, further investigations are needed to examine the interaction of phages with the host using killing curves and stability experiments. Future experiments should also include a greater range of test bacterial isolates which cause disease in onions (e.g. Dickeya spp., Xanthomonas spp. and Pseudomonas spp.). The use of standard control isolates in overlay assays and bioassays, and more replicated laboratory and field studies would help to further prove the efficacy of these phages for control of a broader range of bacterial isolates pathogenic to onion. Further studies are also needed to investigate the epidemiology and pathogenicity of soft rot in onions for detection of all pathogens known to cause this disease in Northern Ireland.

\section{Conclusions}

This study provides the first evidence of the use of Siphoviridae and Podoviridae bacteriophages as a plant protection biocontrol cocktail formulation to protect onions against natural bacterial soft rot infection under field conditions. As a significant protective effect against natural soft rot infection has been observed, future work should seek to further optimize and test the phage cocktail under laboratory and field conditions.

Supplementary Materials: The following are available online at http://www.mdpi.com/1999-4915/12/2/150/s1, Table S1: Bacteria isolates used in this study, Table S2: Conserved domains of bacteriophages isolated in this study, 
Table S3: Features of annotated bacteriophages genomes in this study by RAST, Virulence Finder, Res Finder 3.1 and ToxFinder, Table S4: RAST annotations.

Author Contributions: Conceptualization, M.A.Z.-M. and G.K.Y.; methodology, M.A.Z.-M., G.K.Y. and K.C.; software, M.A.Z.-M.; formal analysis, M.A.Z.-M. and J.T.; investigation, M.A.Z.-M.; resources, C.C.F., G.K.Y., R.O.H. and K.C.; data curation, M.A.Z.-M.; writing-original draft preparation, M.A.Z.-M. and R.O.H; writing-review and editing, M.A.Z.-M., K.C., R.O.H., C.F., J.T. and G.K.Y.; visualization, M.A.Z.-M.; supervision, K.C., R.O.H., C.F. and G.K.Y.; funding acquisition, G.K.Y., M.A.Z.-M. and K.C. All authors have read and agreed to the published version of the manuscript.

Funding: The M.A.Z-M. was funded by Department of Agriculture, Environment and Rural Affairs (DAERA), Northern Ireland by PhD studentship.

Acknowledgments: The authors would like to thank to: J. Brazil, J. Larkin, C. Plahe, J. Morgan, K. O'Neill, F. McHardy and the other Agri-Food and Biosciences Institute (AFBI), Newforge Lane Belfast staff and Queen's University Belfast students for their assistance in field trials 2016 - 2018. The authors also would like to thank to Statistical Analysis Branch, AFBI for their assistance in field trials data analysis. The authors are grateful to Victoria Smith and Deborah Moffett for the advice with the characterization of bacteriophages using transmission electron microscopy and next-generation sequencing at AFBI, VSD, Stormont, Molecular Virology Division. The authors are also grateful for provision of samples by DAERA.

Conflicts of Interest: The authors declare no conflict of interest. The funders had no role in the design of the study; in the collection, analyses, or interpretation of data; in the writing of the manuscript, or in the decision to publish the results.

\section{References}

1. Food and Agriculture Organization of the United Nations. The Future of Food and Agriculture: Trends and Challenges. Available online: http://www.fao.org/3/a-i6583e.pdf (accessed on 4 November 2017).

2. Parnell, J.J.; Berka, R.; Young, H.A.; Sturino, J.M.; Kang, Y.; Barnhart, D.M.; DiLeo, M.V. From the lab to the farm: an industrial perspective of plant beneficial microorganisms. Front. Plant Sci. 2016, 7, 1110. [CrossRef] [PubMed]

3. Food and Agriculture Organization of the United Nations. Available online: http://www.fao.org/faostat/en/ \#data/QC (accessed on 18 January 2019).

4. Vahling-Armstrong, C.; Dung, J.K.S.; Humann, J.L. Effects of postharvest onion curing parameters on bulb rot caused by Pantoea agglomerans, Pantoea ananatis and Pantoea allii in storage. Plant Pathol. 2015, 65, 536-544. [CrossRef]

5. Conn, E.K.; Lutton, J.S.; Rosenberger, S.A. Onion Disease Guide. Plant Health 2012, 72.

6. Hadizadeh, I.; Peivastegan, B.; Hannukkala, A.; van der Wolf, J.M.; Nissinen, R. Biological control of potato soft rot caused by Dickeya solani and the survival of bacterial antagonists under cold storage conditions. Plant Pathol. 2018, 68, 297-311. [CrossRef]

7. Lee, C.J.; Lee, A.J.T.; Kwon, A.J.H.; Kim, B.B.C.; Park, C.; Park, W. Occurrence of bacterial soft rot of onion plants caused by Burkholderia gladioli pv. alliicola in Korea. Australas. Plant Pathol. 2005, 34, 287-292. [CrossRef]

8. Waleron, M.; Waleron, K.; Łojkowska, E. First report of Pectobacterium carotovorum subsp. brasiliense causing soft rot on potato and other vegetables in Poland. Plant Dis. 2015, 99, 1271. [CrossRef]

9. Palacio-Bielsa, A.; Cambra, M.A.; Lopez, M.M. First report of bacterial soft rot on onion caused by Dickeya sp. (ex Pectobacterium chrysanthemi) in Spain. Plant Pathol. 2006, 56, 722. [CrossRef]

10. Tsai, W.A.; Lin, P.R.; Huang, C.J. First report of Dickeya fangzhongdai causing soft rot disease of Welsh onion in Taiwan. J. Plant Pathol. 2019, 101, 797-798. [CrossRef]

11. Adriaenssens, E.M.; van Vaerenbergh, J.; Vandenheuvel, D.; Dunon, V.; Ceyssens, P.J.; de Proft, M.; Kropinski, A.M.; Noben, J.P.; Maes, M.; Lavigne, R. T4-related bacteriophage LIMEstone isolates for the control of soft rot on potato caused by 'Dickeya solani'. PLoS ONE 2012, 7, e33227. [CrossRef]

12. Lim, J.A.; Jee, S.; Lee, D.H.; Roh, E.; Jung, K.; Oh, C.; Heu, S. Biocontrol of Pectobacterium carotovorum subsp. carotovorum using bacteriophage PP1. J. Microbiol. Biotechnol. 2013, 23, 1147-1153. [CrossRef]

13. Czajkowski, R.; Smolarska, A.; Ozymko, Z. The viability of lytic bacteriophage $\Phi D 5$ in potato-associated environments and its effect on Dickeya solani in potato (Solanum tuberosum L.) plants. PLoS ONE 2017, 12, e0183200. [CrossRef] 
14. Svircev, A.; Roach, D.; Castle, A. Framing the future with bacteriophages in agriculture. Viruses 2018, 10, 218. [CrossRef]

15. Lang, J.M.; Gent, D.H.; Schwartz, H.F. Management of Xanthomonas leaf blight of onion with bacteriophages and a plant activator. Plant Dis. 2007, 91, 871-878. [CrossRef]

16. Czajkowski, R.; Ozymko, Z.; de Jager, V.; Siwinska, J.; Smolarska, A.; Ossowicki, A.; Narajczyk, M.; Lojkowska, E. Genomic, proteomic and morphological characterization of two novel broad host lytic bacteriophages $\Phi$ PD10.3 and ФPD23.1 infecting pectinolytic Pectobacterium spp. and Dickeya spp. PLoS ONE 2015, 10, e0119812. [CrossRef]

17. Buttimer, C.; Hendrix, H.; Lucid, A.; Neve, H.; Noben, J.P.; Franz, C.; O’Mahony, J.; Lavigne, R.; Coffey, A. Novel N4-Like Bacteriophages of Pectobacterium atrosepticum. Pharmaceuticals 2018, 11, 45. [CrossRef]

18. European Chemicals Agency (ECHA) Home Page. Available online: https:/echa.europa.eu/regulations/ biocidal-products-regulation/authorisation-of-biocidal-products (accessed on 22 May 2012).

19. Fravel, D.R. Commercialization and implementation of biocontrol. Annu. Rev. Phytopathol. 2005, 43, 337-359. [CrossRef]

20. Zaczek-Moczydłowska, M.A.; Fleming, C.C.; Young, G.K.; Campbell, K.; O’Hanlon, R. Pectobacterium and Dickeya species detected in vegetables in Northern Ireland. Eur. J. Plant Pathol. 2019, 154, 635-647. [CrossRef]

21. Fortier, L.C.; Moineau, S. Morphological and genetic diversity of temperate phages. Appl. Environ. Microbiol. 2007, 73, 7358-7366. [CrossRef]

22. Kutter, E. Phage Host Range and Efficiency of Plating. In Bacteriophages; Humana Press: Totowa, NJ, USA, 2009; Volume 501, pp. 141-149.

23. Devaney, R.; Trudgett, J.; Trudgett, A.; Meharg, C.; Smyth, V. A metagenomic comparison of endemic viruses from broiler chickens with runting-stunting syndrome and from normal birds. Avian Pathol. 2016, 45, 616-629. [CrossRef]

24. Altschul, S.F.; Gish, W.; Miller, W.; Myers, E.W.; Lipman, D.J. Basic local alignment search tool. J. Mol. Biol. 1990, 215, 403-410. [CrossRef]

25. Brettin, T.; Davis, J.J.; Disz, T.; Edwards, R.A.; Gerdes, S.; Olsen, G.J.; Olson, R.; Overbeek, R.; Parrello, B.; Pusch, G.D.; et al. RASTtk: A modular and extensible implementation of the RAST algorithm for building custom annotation pipelines and annotating batches of genomes. Sci. Rep. 2015, 10, 8365. [CrossRef]

26. Marchler-Bauer, A.; Bo, Y.; Han, L.; He, J.; Lanczycki, C.J.; Lu, S.; Chitsaz, F.; Derbyshire, M.K.; Geer, R.C.; Gonzales, N.R.; et al. CDD/SPARCLE: Functional classification of proteins via subfamily domain architectures. Nucleic Acids Res. 2017, 45, 200-203. [CrossRef]

27. Center for Genomic Epidemiology. ResFinder 3.2. Available online: https://cge.cbs.dtu.dk/services/ResFinder/ (accessed on 16 October 2019).

28. Center for Genomic Epidemiology. Virulence Finder 2.0. Available online: https://cge.cbs.dtu.dk/services/ VirulenceFinder/ (accessed on 16 October 2019).

29. Center for Genomic Epidemiology. ToxFinder 1.0. Available online: https://cge.cbs.dtu.dk/services/ToxFinder/ (accessed on 16 October 2019).

30. Bdliya, B.S.; Langerfeld, E.; Rudolph, K. A modified crystal violet pectate (CVP) medium for detection and isolation of soft rot Erwinia spp. from plant materials. J. Plant Dis. Protect. 2004, 111, 506-515.

31. Czajkowski, R.; Pérombelon, M.C.M.; Jafra, S.; Lojkowska, E.; Potrykus, M.; van der Wolf, J.M.; Sledz, W. Detection, identification and differentiation of Pectobacterium and Dickeya species causing potato blackleg and tuber soft rot: A review. Ann. Appl. Biol. 2015, 166, 18-38. [CrossRef]

32. Dutkiewicz, J.; Mackiewicz, B.; Lemieszek, M.K.; Golec, M.; Skórska, C.; Góra-Florek, A.; Malinowski, J. Pantoea agglomerans: A mysterious bacterium of evil and good. Part II. Deleterious effects: Dust-borne endotoxins and allergens-Focus on grain dust, other agricultural dusts and wood dust. Ann. Agric. Environ. Med. 2016, 23, 6-9. [CrossRef] [PubMed]

33. Tho, K.E.; Wiriyajitsomboon, P.; Hausbeck, M.K. First report of Pantoea agglomerans causing onion leaf blight and bulb rot in Michigan. Plant Dis. 2015, 99, 1034. [CrossRef]

34. Hu, J. First report of onion bulb rot caused by Pantoea agglomerans in Arizona. Dis. Notes. 2019, $103,1408$. [CrossRef]

35. Czajkowski, R. Bacteriophages of soft rot Enterobacteriaceae-A minireview. FEMS Microbiol. Lett. 2016, 363, fnv230. [CrossRef] 
36. Carstens, A.B.; Djurhuus, A.M.; Kot, W.; Hansen, L.H. A novel six-phage cocktail reduces Pectobacterium atrosepticum soft rot infection in potato tubers under simulated storage conditions. FEMS Microbiol. Lett. 2019, 366. [CrossRef]

37. Smolarska, A.; Rabalski, L.; Narajczyk, M.; Czajkowski, R. Isolation and phenotypic and morphological characterization of the first Podoviridae lytic bacteriophages $\phi A 38$ and $\phi A 41$ infecting Pectobacterium parmentieri (former Pectobacterium wasabiae). Eur. J. Plant. Pathol. 2018, 150, 413-425. [CrossRef]

38. Kabanova, A.; Shneider, M.; Bugaeva, E.; Ha, V.T.N.; Miroshnikov, K.; Korzhenkov, A.; Kulikov, E.; Toschakov, S.; Ignatov, A.; Miroshnikov, K. Genomic characteristics of vB_PpaP_PP74, a T7-like Autographivirinae bacteriophage infecting a potato pathogen of the newly proposed species Pectobacterium parmentieri. Arch. Virol. 2018, 163, 1691-1694. [CrossRef]

39. Alič, Š.; Naglič, T.; Tušek-Žnidarič, M.; Ravnikar, M.; Rački, N.; Peterka, M.; Dreo, T. Newly isolated bacteriophages from the Podoviridae, Siphoviridae, and Myoviridae families have variable effects on putative novel Dickeya spp. Front. Microbiol. 2017, 8, 1870. [CrossRef] [PubMed]

40. Adriaenssens, E.M.; Ceyssens, P.J.; Dunon, V.; Ackermann, H.W.; Van Vaerenbergh, J.; Maes, M.; De Proft, M.; Lavigne, R. Bacteriophages LIMElight and LIMEzero of Pantoea agglomerans, belonging to the "phiKMV-like viruses". Appl. Environ. Microbiol. 2011, 77, 3443-3450. [CrossRef] [PubMed]

41. Šimoliūnas, E.; Šimoliūnienè, M.; Kaliniene, L.; Zajančkauskaitè, A.; Skapas, M.; Meškys, R.; Truncaitė, L. Pantoea Bacteriophage vB_PagS_Vid5: A low-temperature Siphovirus that harbors a cluster of genes involved in the biosynthesis of archaeosine. Viruses 2018, 10, 583.

42. Lim, J.A.; Heu, S.; Park, J.; Roh, E. Genomic characterization of bacteriophage vB_PcaP_PP2 infecting Pectobacterium carotovorum subsp. carotovorum, a new member of a proposed genus in the subfamily Autographivirinae. Arch. Virol. 2017, 162, 2441-2444. [CrossRef] [PubMed]

43. Lee, D.H.; Lee, J.H.; Shin, H.; Ji, S.; Roh, E.; Jung, K.; Ryu, S.; Choi, J.; Heu, S. Complete genome sequence of Pectobacterium carotovorum subsp. carotovorum bacteriophage My1. J. Virol. 2012, 86, 11410-11411. [CrossRef]

44. Park, T.H. The National Center for Biotechnology Information Home Page. Complete genome sequence of bacteriophage (DU_PP_V) infecting Pectobacterium spp. Available online: https://www.ncbi.nlm.nih.gov/ nuccore/1275231159 (accessed on 12 November 2017).

45. Day, A.; Ahn, J.; Fang, X.; Salmond, G.P.C. Environmental bacteriophages of the emerging Enterobacterial phytopathogen, Dickeya solani, show genomic conservation and capacity for horizontal gene transfer between their bacterial hosts. Front. Microbiol. 2017, 8, 165. [CrossRef]

46. Fillol-Salom, A.; Alsaadi, A.; Sousa, J.A.M.; Zhong, L.; Foster, K.R.; Rocha, E.P.C.; Penadés, J.R.; Ingmer, H.; Haaber, J. Bacteriophages benefit from generalized transduction. PLoS Pathog. 2019, 15, e1007888. [CrossRef]

47. Zhang, F.; Song, G.; Tian, Y. Anti- CRISPRs: The natural inhibitors for CRISPR-Cas systems. Anim. Model. Exp. Med. 2019, 29, 69-75. [CrossRef]

48. Maxwell, K.L. Phages Fight Back: Inactivation of the CRISPR-Cas bacterial immune system by anti-CRISPR proteins. PLoS Pathog. 2016, 12, e1005282. [CrossRef]

49. Zhu, Y.; Zhang, F.; Huang, Z. Structural insights into the inactivation of CRISPR-Cas systems by diverse anti-CRISPR proteins. BMC Biol. 2018, 16, 32. [CrossRef]

50. Dupuis, B. The movement of potato virus Y (PVY) in the vascular system of potato plants. Eur. J. Plant Pathol. 2017, 147, 365-373. [CrossRef]

51. Buttimer, C.; McAuliffe, O.; Ross, R.P.; Hill, C.; O’Mahony, J.; Coffey, A. Bacteriophages and bacterial plant diseases. Front. Microbiol. 2017, 8, 34. [CrossRef] [PubMed]

52. Schmerer, M.; Molineux, I.J.; Bull, J.J. Synergy as a rationale for phage therapy using phage cocktails. Peer J. 2014, 2, e590. [CrossRef]

(C) 2020 by the authors. Licensee MDPI, Basel, Switzerland. This article is an open access article distributed under the terms and conditions of the Creative Commons Attribution (CC BY) license (http://creativecommons.org/licenses/by/4.0/). 